\title{
BIDIRECTIONAL AND UNIDIRECTIONAL COMITATIVE CONSTRUCTIONS IN HUNGARIAN: A PSYCHOLINGUISTIC INVESTIGATION AT THE INTERFACE OF ARGUMENT STRUCTURE AND SEMANTICS*
}

\author{
ISTVÁN FEKETE - CSABA PLÉH \\ Department of Cognitive Science, \\ Budapest University of Technology and Economics \\ Stoczek u. 2., H-1111 Budapest, Hungary \\ ifekete@cogsci.bme.hu; pleh@cogsci.bme.hu
}

\begin{abstract}
This paper explores how bidirectional and unidirectional comitative constructions are processed at the level of argument structure. Bidirectional comitative constructions describe events where the two actors undergo the same effect described by the predicate (e.g., John was kissing with Mary), whereas unidirectional comitative constructions describe events in which one of the actors is the agent, and the other one is the patient (e.g., John was messing with Mary). In particular, we used the self-paced reading paradigm to determine if the two constructions access distinct mental representations. The findings suggest that distinct mental representations are activated automatically by bidirectional and unidirectional verbs during online language comprehension.
\end{abstract}

Keywords: comitative-instrumental suffix, argument structure, self-paced reading, sentence processing, anaphora resolution

\section{Introduction}

How are verb meanings processed? Two competing but not mutually exclusive approaches to verb representation are as follows (i) language users draw inferences from thematic roles of arguments (e.g., Dowty 1991), or (ii) they understand events in terms of non-linguistic mental models (i.e., routinely imagining the scene encoded in the sentence,

* This research was supported by OTKA (grant no. TS 049840). Thanks are due to Anna Babarczy and György Rákosi for comments on earlier versions of this paper. 
e.g., Zwaan-Radvansky 1998). The first approach is based on the assumption that verbs are represented as complex semantic templates. The second approach claims that language understanding recruits modalityspecific information. Experimental studies have shed light on the nature and time course of the processing of thematic roles and argument structure (Adams et al. 1998; Carlson-Tanenhaus 1988; Dowty 1991; Goldberg 1995; Levin 1993; MacDonald et al. 1994; Mitchell 1987; Prichett 1992; van Gompel-Pickering 2001). For example, Mitchell (1987) found that verbs automatically project their argument structures; the doctor is read slower after an intransitive verb, such as sneezed, than after a transitive verb, such as visited:

(1) (a) After the child had sneezed the doctor prescribed a course of injections.

(b) After the child had visited the doctor prescribed a course of injections.

The effect is due to a clause boundary in (1a) based on the argument structure of the verb in the first clause. Taken together, these studies suggest that thematic and argument structures are computed automatically when the verb meaning is activated to construct a schematic representation of the event described. It is commonly accepted, however, that thematic roles and syntactic arguments do not solely constitute verb meanings. For example, recent studies have suggested that language users compute sentential meaning via non-linguistic mental simulation (Richardson et al. 2003; Zwaan et al. 2004). One theoretical framework of this line of research is proposed by Zwaan and Radvansky (1998) who claim that language comprehenders use situation models (mental models) which are integrated mental representations of the events described.

The current study raises the question whether there is empirical evidence for the psycholinguistic reality of distinct mental representations for bidirectional and unidirectional comitative constructions (for an overview of comitative constructions, see Rákosi 2003). Bidirectional (comitative) constructions describe events where the two actors undergo the same effect described by the predicate (e.g., John was kissing with Mary), whereas unidirectional (instrumental-like) constructions describe events in which one of the actors is the agent, and the other one is the patient (e.g., John was messing with Mary). If thematic roles are immediately processed when the verb is encountered, as previous findings show, then differences in reading times should emerge. Given that there is a semantic difference between the two constructions in terms of the thematic status of the second arguments, we expect readers to be sensi- 
tive to this distinction based on Mitchell (1987), who showed that readers automatically project argument structure.

Hungarian, which has a relatively free word order, allows us to investigate word-order effects, too. Here, the question arises, for example, how a conjoined-NP subject is interpreted ('the girl with the boy'). Do readers have a tendency to parse such a chunk as a symmetrical construction? It is also possible to test whether anaphors referring to either or both of the actors of a unidirectional or bidirectional construction are read differently. The rationale for this hypothesis is that there may emerge a difference in the processing of surface and deep anaphora (Sag-Hankamer 1984; Pléh 1989; 1998; Pléh-MacWhinney 1987). We also expect readers to be sensitive to the resolution of these two types of anaphors.

The linguistic background of this speculation is the distinction between surface and deep anaphora proposed by Hankamer and Sag (1976). In this paper, we address each of the questions raised above. The studies in this paper focus on the representation of relational information (who did what to whom) in the mental model.

\section{Mental models}

The question arises if verb meanings and sentential meaning include information about events beyond thematic features (participant slots). Recent research has found, for example, that language comprehension routinely recruits perceptual-motor simulations (Glenberg-Kaschak 2002; Kaschak-Glenberg 2000; Stanfield-Zwaan 2001; Zwaan et al. 2004). Mental simulation as a possible mechanism has been postulated to describe the dynamic non-linguistic processes going on during language comprehension: the comprehender mentally simulates the situational content of utterances. The situational content can involve perceptual, motor, affective and social inferences and simulations. This level of processing is the situational level; the other two are the lexical and the propositional levels.

In our case, mental simulation refers to mental processes that capture symmetry and asymmetry at this non-linguistic representational level. This is a situation model which encodes the scenario described by the predicate. The comprehender presumably pictures a social scene, a microworld with two agents who are either equal partners in terms of their involvement in the action, or are in an asymmetric relationship. Mental simulation is hypothesized to play a crucial role because the encoding of symmetrical and asymmetrical events involve higher semantics. 
Mental models are psychological representations of situations. A mental model is an internal representation of a situation in which objects or concepts are linked to other objects or concepts. They were first proposed by the Scottish psychologist Kenneth Craik (1943), who postulated that the mind constructs these models of reality (a "small-scale model" of external reality) for the anticipation of events, or to reason. These models are constructed in working memory in present-day terminology.

Mental models can emerge from perception, discourse comprehension, or imagination (Johnson-Laird 1983; Marr 1982). An important aspect of mental models is that their mental structure corresponds to the real structure of what they represent. However, they are more abstract than mental images. The theory of mental models refutes the assumption that humans employ a kind of propositional logic when making inferences about the events of the world.

Zwaan and Radvansky (1998) claim that people typically identify at least five dimensions of situations: time, space, causation, intentionality, and protagonists. Many studies have investigated protagonists and objects in anaphor resolution tasks. The various components of the situation model are separate (ibid.), and they can be primed individually. Boroditsky (2000), for example, found that the use of a temporal reference perspective can be primed by a spatial reference perspective (ego moving or object moving). Thus, if people had just verified a sentence describing a spatial scenario that used a particular frame of reference (ego moving or object moving), they tended to interpret a temporal expression in terms of the corresponding frame of reference. Her results demonstrate priming of a structural aspect of the situation model that is postulated to be shared between the spatial and temporal dimensions.

The comprehension of the two aforementioned comitative constructions is hypothesized to take place in the situation-model. The comprehender presumably builds a corresponding mental model of a scene with two actors. This model of comprehension goes beyond the propositional level (the latter as proposed, e.g., by Kintsch 1998). The purpose of such an experiment is to investigate how conceptual-level representations are mapped onto the syntactic-semantic level. We suppose that mental models play a central role in representing states of affairs and social actions, such as bidirectional and unidirectional events.

Mental models can facilitate inferences drawn from linguistic descriptions. Anaphoric inferences provide a ground to investigate implicitly if mental models are generated during online sentence comprehension. We 
expect readers to resolve surface anaphors faster than deep anaphors because deep anaphors access non-linguistic representations, while surface anaphors are resolved purely at the linguistic (syntactic) level.

In the following, three experiments are presented that investigate the effect of word order (Experiment 1 vs. Experiment 2) and the effect of adjuncthood (Experiments 1, 2 vs. Experiment 3) on the interpretation of bi- and unidirectional comitative constructions. We refer to optional arguments as adjuncts in the present paper. Cross-sentential anaphoric processing was investigated in each of the conditions in the three experiments.

\section{The experiments}

\subsection{Experiments 1 and 2}

\subsubsection{Participants}

In Experiment 1, 62 Hungarian students, in Experiment 2, 30 Hungarian students participated for course credit.

\subsubsection{Materials and design}

40 experimental probes and 20 filler probes were constructed. The experimental probes contained 20 bidirectional comitative probes and 20 unidirectional comitative probes (see Appendix A). Each probe consisted of two sentences. The first sentence described an event with two actors, the second sentence described another one whose content was related to that of the first sentence. The second sentence always contained an anaphor (singular/plural), which was a verb (Hungarian is a pro-drop language, ${ }^{1}$ see É. Kiss 2002). The second sentences were the same across the categories of the variable verb type (bidirectional/unidirectional). Test verbs were pairwise matched for syllabic length and lemma frequency ${ }^{2}$ so that the lemma frequencies of the unidirectional verbs were higher (mean lemma frequency of unidirectional verbs: 4633.6; mean lemma frequency of bidirectional verbs: 1880.9). The lemma frequencies can be seen

${ }^{1}$ Certain classes of pronouns are omitted when they are pragmatically inferable (pronoun-dropping).

2 The lemma frequencies were obtained from the MOKK web-based frequency database: http://mokk.bme.hu/resources/webcorpus/index_html (Halácsy et al. 2004; Kornai et al. 2006). 
in Appendix B. The two agents in the test sentences were chosen as neutral and equal in terms of the relationship, to control for any effect this could impose on the processing.

The experimental verbs were tested on directionality in a metalinguistic judgement study: 8 raters judged whether the critical verbs were unidirectional or bidirectional; their task was to determine whether the meaning of the sentences remains the same if the order of the agents are changed. Each matched verb pair had the same number of syllables. Appendix B shows the verb stimuli with their lemma frequencies. In each matched-pair the test sentences were exactly the same up to the point of the critical verb. The second sentence (the continuation) was exactly the same in a matched-pair.

\subsubsection{Procedure}

The task was self-paced word-by-word reading with a stationary window display (Just et al. 1982) using E-Prime psychological software. Each trial began with a fixation cross on the centre of the screen. Participants pressed the spacebar to reveal each word of the sentence. As each new word appeared in the sentence, the preceding word disappeared. The amount of time the participant spent reading each word was recorded as the time between key-presses. After the final word of each item, a statement appeared to which participants were invited to react (e.g., "The girl was messing with the boy" TRUE/FALSE): participants pressed one of two keys to respond "yes" or "no". No feedback was given for correct responses. Participants were asked to read sentences at a natural rate, but to read as quickly and accurately as they could, and to make sure that they understood what they read. They were told that the time they took to answer the question was not measured. Before the main experiment, two practice probes and questions were presented in order to familiarize the participant with the task. A session was 10 minutes long on the average.

In Experiment 1, mean reading times were analysed (i) in the region of verbs (the last word) in the first sentences of experimental trials, as well as (ii) in the region of the anaphors (the first word) in the second sentences of experimental trials. The first dependent variable (i) tested whether conjoined-NP subjects were interpreted as bidirectional constructions. Our hypothesis was that sentences with this word order (NNV) would be interpreted faster with bidirectional verbs than with unidirectional ones. The second dependent variable (ii) measured if singular and plural 
anaphors were resolved differently after bidirectional and unidirectional constructions.

In Experiment 2, the verbs separated the two arguments in the critical sentences. Mean reading times were analysed (i) in the region of verbs (the third word) in the first sentences of experimental trials and in the region of the second arguments after the verb, as well as (ii) in the region of the anaphors (the first word) in the second sentences of experimental trials. Reaction time measurement in the first sentences of experimental trials (i) tested whether bidirectional and unidirectional constructions were processed differently at the level of argument structure. Our intuitive hypothesis was that sentences with this word order (NVN) would be interpreted faster with unidirectional verbs than with bidirectional ones. The second dependent variable (ii) measured if singular and plural anaphors were resolved differently after bidirectional and unidirectional constructions.

\subsubsection{Results and discussion}

In both of the experiments the incorrect trials were removed from the analysis, and the mean of median reading times were taken. Figure 1 illustrates the difference in reading times between comitative (bidirectional, e.g., 'The girl with the boy partied') and instrumental(-like) (unidirectional, e.g., 'The girl with the boy bantered') constructions in Experiment 1 (NNV-setting). It can be seen that comitative constructions were read significantly faster than instrumental(-like) ones $(t(61)=$ $-2.625, p<0.05)$.

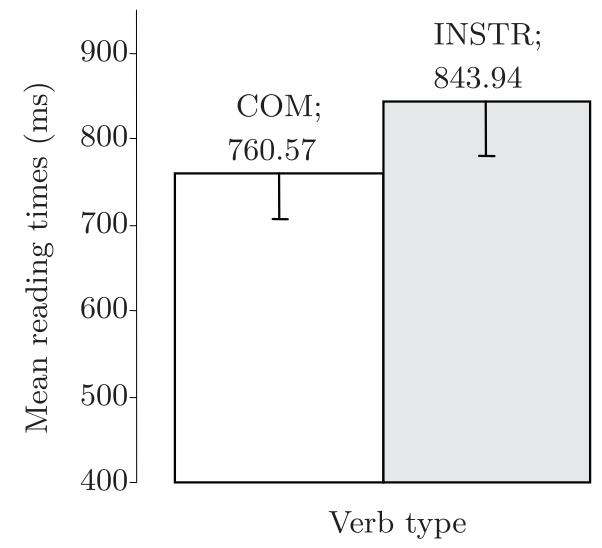

Fig. 1

Main effect of verb type in Experiment 1 (standard error is indicated)

Acta Linguistica Hungarica 58, 2011 
Presumably, the sentence-initial NP and the second NP are taken to be a conjoined Subject-NP $\left[\mathrm{NP} 1_{\text {human }}+\mathrm{NP} 2(\text { 'with') })_{\text {human }}+\mathrm{V}\right.$ (past)]. This interpretation couples with the comitative: 'the girl and the boy' = 'the girl with the boy' (Dimitriadis 2008; Rákosi 2003).

Singular anaphoric verbs were processed significantly faster after comitative constructions than (the same ones) after instrumental-type constructions $^{3}(t(61)=-2.120, p<0.05)$ :

Table 1

The processing times of the anaphoric verbs in Experiment 1

\begin{tabular}{lcc}
\hline Anaphor type & Mean (ms) & Std. dev. \\
\hline COM_plural & 708.38 & 245.78 \\
COM_singular & $\mathbf{7 1 1 . 9 4}$ & 314.73 \\
INSTR_plural & 749.14 & 315.92 \\
INSTR_singular & $\mathbf{7 9 3 . 0 6}$ & 320.27 \\
\hline
\end{tabular}

The general ease in the processing of anaphoric verbs after comitative constructions is presumably due to the ease of the processing of comitative constructions in the previous sentence, given word order NNV. The difference between the processing of plural anaphors in the two conditions is not significant $(t(61)=-1.163$, n.s.). Plural anaphors were read significantly faster after comitative constructions than singular anaphors after instrumental (unidirectional) constructions $(t(61)=-2.253, p<0.05$ ): e.g., 'The girl with the boy partied. They hooked up...' vs. 'The girl with the boy bantered. She broke into a smile.'

All in all, the differences in the resolution of anaphors show us that comitative and instrumental constructions are processed differently. The specific difference in the mental models is, however, left unanswered. Suffice it to say that the evidence is interpreted as supporting Kehler's (2002) hypothesis that the processing patterns observed in pronoun processing reflect more general cognitive inference processes underlying the establishment of discourse coherence. It may, however, well be the case that the difference in anaphor resolution only reflects the ease or difficulty with which language users bind the subject-antecedent to the anaphor.

${ }^{3}$ Only four-syllabic anaphors were included in the analysis in order to control for the effect of word length. 
The ease or difficulty is contingent on the type of the construction the antecedent is embedded in.

Experiment 2 differed from Experiment 1 in that it changed the word order of Experiment 1 to NVN. Hence, the critical verbs were presented between the two NPs. In accordance with our expectations, there were no differences in reading times between the two types of verbs $(t(29)=-0.222, p<0.826, \mathrm{n}$. s. $)$. This is due to the fact that the critical verbs were counterbalanced on lemma frequency and syllabic length. Furthermore, the critical verbs in the NVN-setting were read 200-300 ms faster than in the previous experiment where they were presented in the last position of the sentence. The slower reading times in the region of the critical verbs in Experiment 1 reflect sentence integration costs, whereas in the present experiment only the first NP and the critical verb were encountered but not the second NP. Figure 2 illustrates that in the NVN-setting the second arguments were read significantly faster after instrumental(-like) verbs (unidirectional verbs) $(t(29)=2.538, p<0.05)$.

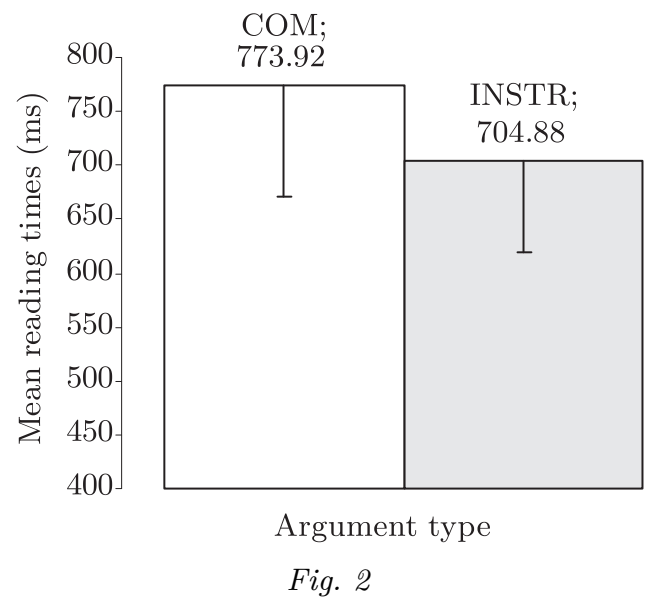

Mean reading times of the arguments after the critical verbs in Experiment 2 (standard error is indicated). Mean reading times reflect reading time data in the region of the nouns

This difference in the reading times of the second NPs can be explained by the psycholinguistic distinction between arguments and adjuncts. We speculated that the difference in processing times is due to the status of the second NPs (arguments or adjuncts), rather than to the semantics of the preceding verbs. This question is taken up in Experiment 3, in which only two-argument verbs are tested (verbs that take two syntactic 
arguments). The following table shows the mean reading times of the second NPs by item (NVN-setting).

Table 2

A comparison of the reading times of the NPs after the critical verbs in Experiment 2

\begin{tabular}{lcrcc}
\hline Verb pairs & $\begin{array}{c}\text { RT of the NP } \\
\text { after the verb (ms) }\end{array}$ & $t$ & \multicolumn{1}{c}{$p$} \\
\hline bulizott 'partied' - kikezdett 'made a pass at' & $770.17-530.40$ & 2.073 & .047 \\
sétálgatott 'walked' - incselkedett 'joshed' & $702.67-540.78$ & 1.965 & .059 \\
találkozott 'met' - csipkelödött 'japed' & $781.48-654.05$ & 1.267 & .215 \\
tegezödött 'theed'--szimpatizált 'liked' & $1315.08-908.42$ & 2.908 & .007 \\
párbajozott 'duelled' - foglalkozott 'dealt' & $98958-943.70$ & 0.274 & .786 \\
énekelt 'sang' - ordított 'shouted' & $1010.67-1062.45$ & -0.315 & .755 \\
csókolózott 'kissed'- együttérzett 'sympathized' & $598-734.35$ & -1.396 & .173 \\
verekedett 'fought'-csúfolódott 'mocked' & $1316.65-1209.62$ & 0.623 & .538 \\
borozott 'drank wine'- törödött 'cared for' & $957.25-866.07$ & 0.671 & .508 \\
mulatozott 'racketed'- gúnyolódott 'jested' & $1104.22-1185.81$ & -0.613 & .545 \\
\hline
\end{tabular}

\subsection{Experiment 3}

Experiment 3 was constructed to eliminate adjuncts. Therefore, in this experiment only such verbs were used that neccesarily take two arguments at the syntactic level (such as mess with). The major focus was on the reading times of the second arguments of these unidirectional and bidirectional comitative verbs as well as the resolution of the anaphors. The experimental sentences were presented in NVN-order, as in Experiment 2.

We hypothesized that there would be a reading time difference in the region of the second arguments, which is not due to the nature of the status of the NP (adjuct or argument). This hypothesis was based on the assumption that unidirectional constructions (NVN) are similar to SVO-constructions, and thus they are comprehended more easily than comitative NVN-constructions. Our second hypothesis concerned the resolution of the anaphors (anaphoric verbs): we assumed that the binding of a singular anaphor to the subject is easier when the subject is the agent of a unidirectional construction, since the agent of these constructions is a "better agent" in terms of agenthood. Semantically, the crucial difference between the agents of (i) Mary hit John and (ii) Mary spoke with John is that in former sentence (i) the agent is more active; Mary is the initiator 
of the action, whereas (ii) does not necessarily entail the same degree of involvement of Mary in the action. We speculate that this difference will have an effect on the resolution of anaphors referring to these agents.

\subsubsection{Participants}

72 Hungarian students participated in this study. Nobody was excluded for performing under $75 \%$ of overall accuracy.

\subsubsection{Materials and design}

40 experimental probes and 20 filler probes were constructed. The experimental probes contained 20 bidirectional comitative probes and 20 unidirectional comitative probes. The actors in the sentences were the same as in the previous two experiments, and the filler sentences were also identical. Each probe consisted of two sentences. The logic of this experiment was basically the same as in the previous experiments: the first sentence described an event with two actors, the second sentence described another one whose content was related to that of the first sentence. The second sentence always contained an anaphor (singular/plural), which was a verb. A pair of experimental trials can be seen here: bidirectional: A pék összefogott a patikussal. Megkötötték a szerzödést./Megkötötte vele a szerzódést. 'The baker joined forces with the apothecary. They made a contract./He made a contract with him.' and unidirectional: $A$ pék leszámolt a patikussal. Verekedtek./Verekedett vele. 'The baker squared accounts with the apothecary. They were fighting./He was fighting with him.' The new experimental verbs were tested on directionality in a metalinguistic judgement study. Appendix $\mathrm{C}$ shows the experimental verbs.

\subsubsection{Procedure}

The procedure of Experiment 3 was identical to the previous experiments.

\subsubsection{Results and discussion}

Comitative arguments (COM, arguments after comitative verbs) were read slower than instrumental-like (INSTR) arguments $(t(71)=1.985$, $p<0.05$ ) (see Figure 3, overleaf).

It should, however, be noted that the difference in reading times in the region of the second NPs could be a spill-over effect from the previous word (the critical verbs). Instrumental-like verbs were read significantly 


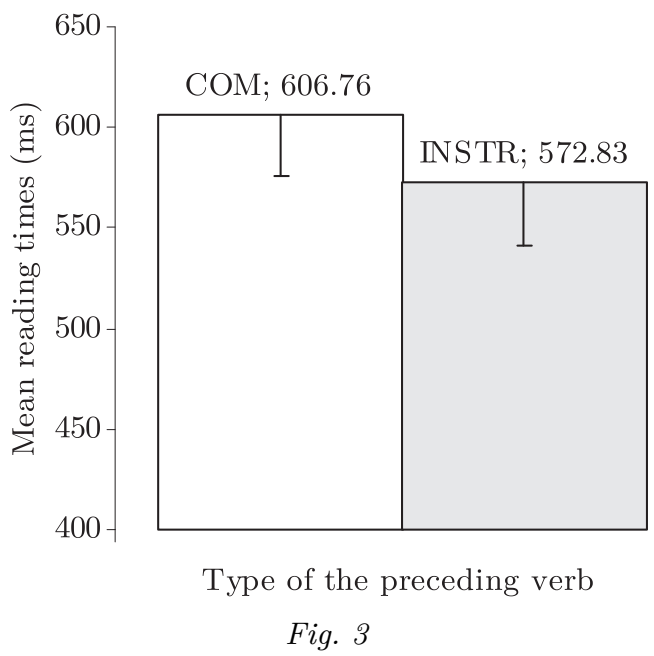

Main reading times of arguments in Experiment 3 (standard error is indicated). Mean reading times reflect reading time data in the region of the nouns

faster than comitative verbs $(t(71)=5.807, p<0.01$ ). (The spill-over region is the NP after the critical verbs.) The following table summarizes the mean of median reading times in the region of the critical verbs.

Table 3

The processing times (ms) of the critical verbs (word 3) in Experiment 3

\begin{tabular}{lcc}
\hline Verb type & Mean & Std. dev. \\
\hline COM_verbs & 565.55 & 215.03 \\
INSTR_verbs & 503.99 & 194.73 \\
\hline
\end{tabular}

Figure 4 illustrates the processing times of the anaphoric verbs. Singular anaphoric verbs were read significantly faster after an instrumental construction than after a comitative construction $(t(71)=2.648, p<$ $0.01)$.

Plural anaphoric verbs were read slower than singular ones in both conditions (plural anaphors, mean: $607.45 \mathrm{~ms}$; singular anaphors, mean: $567.48 \mathrm{~ms} ; p<0.01)$. We have already noted that singular anaphoric verbs were read faster after instrumental-like constructions (e.g., 'The girl was messing with the boy') than the same verbs after comitative constructions (e.g., 'The girl stayed together with the boy'). However, it is not yet clear from the two mental models why comitative (second) 


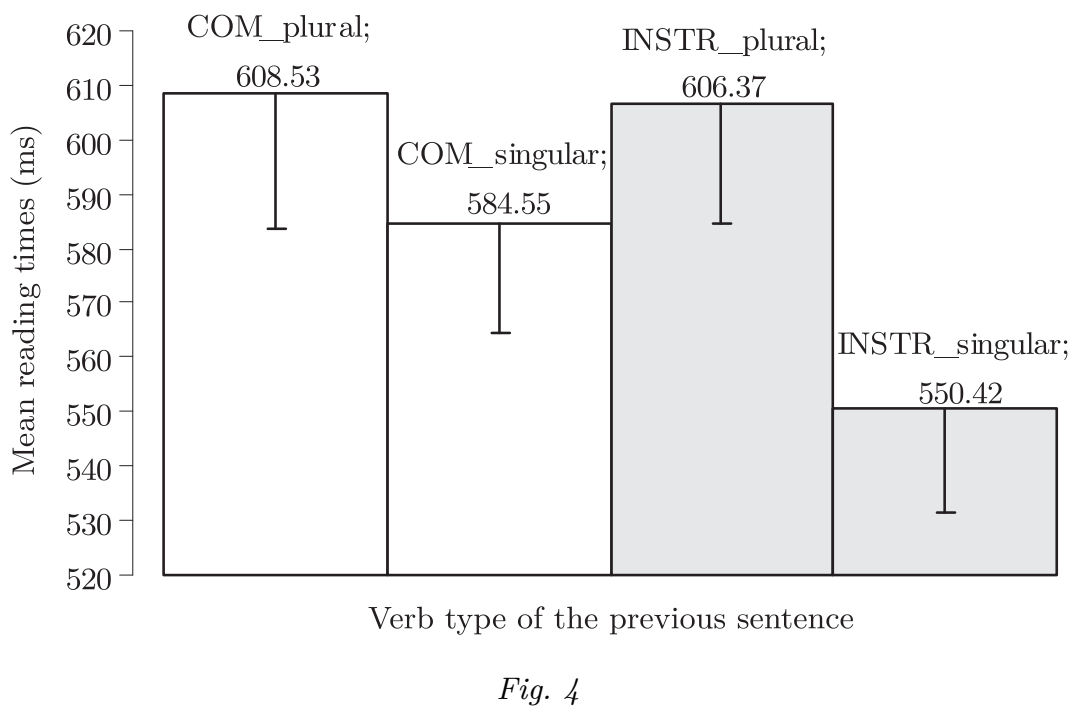

The processing times (ms) of the anaphoric verbs in Experiment 3 (standard error is indicated)

arguments (NVN) should be read slower. We propose here that asymmetric constructions (e.g., 'The girl was messing with the boy') usually take SVO word order (which is common in Hungarian), and thus more easily comprehended, and this is why singular anaphoric verbs are read faster after an instrumental-like construction (antecedent reactivation is easier) than after a bidirectional comitative construction. Following the logic of this assumption about the ease of processing of a singular anaphor after an instrumental construction, we suggest that it is easier to extract the subject from an instrumental construction than from a comitative one (based on the argument mentioned), because the subject of an unidirectional construction is more salient given the essence of the event encoded.

If antecedent reactivation was purely a syntactically-driven process, ${ }^{4}$ then no difference should emerge in the processing of anaphors. Since there is a difference in the processing of singular anaphors after bidirectional and unidirectional constructions, we can conjecture that some other processes also play a role. We propose that the crucial aspect in the mental model is that in a unidirectional construction the first NP (the

4 This could be described with the following syntactic rule: the antecedent of the anaphoric verb is the first $\mathrm{NP} /$ the subject in the first sentence. 
subject) is more salient, and thus, reactivated more easily when the singular anaphoric verb is encountered (this is because of the event structure of the action). In other words, the subject of a unidirectional construction is a volitional agent, wheras that of a bidirectional one is a non-volitional (or less volitional) one.

\section{Conclusion}

Our results show that meaning, specifically relational information, is computed at the level of argument structure. The more complex the structure (NNV), the longer the time to process those structures. An alternative explanation for this effect, however, could be that NNV-constructions are less frequent in Hungarian than NVN-constructions. We have seen that participant roles are activated online during language comprehension. Using Hungarian stimuli again we repeated previous findings that arguments are read significantly faster than adjuncts (Gervain-Pléh 2004). In the NVN-setting processing is easier because in this case the argument structure and the referential context of the verbs are activated (GervainPléh 2004; MacDonald et al. 1994; Prichett 1992).

In Experiment 3, we constructed a set of sentences containing only bidirectional ('The girl stayed together with the boy') and unidirectional ('The girl made a pass at the boy') verbs that take two syntactic arguments. We measured reading times in the region of the second arguments (after the critical verbs) and on the anaphoric verbs (in the second sentences). Comitative arguments were read slower than instrumental arguments; however, we noted that the difference may be attributable to a spillover effect during reading.

We further found in Experiment 3 that singular anaphoric verbs were resolved slower after bidirectional comitative constructions than after asymmetric constructions. We proposed that this shows that symmetric and asymmetric constructions are processed differently. We interpret the difference in the resolution of singular anaphors from a form-based perspective, namely, that a singular anaphoric verb gets more easily connected to its antecedent (the subject of the first sentence), because asymmetric constructions resemble SVO-constructions both in terms of structure and meaning, and the subject NP of unidirectional (asymmetric) constructions is more salient than that of bidirectional ones. (We will argue later that the saliency of the Subject is essentially its prototypicality as an agent.)

Acta Linguistica Hungarica 58, 2011 
The reverse effect (singular anaphoric verbs were processed faster after bidirectional constructions than after unidirectional ones) was observed in Experiment 1: this can be explained by a spill-over effect, namely that unidirectional constructions were processed slower (Exp 1, NNV), and therefore, anaphor resolution is also slower.

Importantly, the difference in the resolution of singular anaphors in Experiment 3 can be explained by linguistic (not imagery-based) theories: anaphor resolution is easier after an agent/patient (asymmetric) construction than after an agent/co-agent(partner) (symmetric) construction, because the agent in the former case is more salient from a semantic point of view (since it is crucial to know who initiated the action, who was the "agentive agent").

Intuitively, the agent of bidirectional constructions is less prototypical for an agent. For example, in the sentence Mary was kissing with John, Mary is less "agentive" than in the sentence Mary kissed John. The latter sentence entails that Mary intentionally instigated the event described by the predicate (kissing), whereas in the former sentence (Mary was kissing with John) both of the NPs are in focus. It seems, therefore, that the agent of bidirectional constructions is not a prototypical volitional agent. This conception is in accord with Dowty's (1991) fuzzy analysis of protoagents; he proposed that volitionality is one of the semantic properties in the representation of agents.

We showed earlier (cf. Experiment 1) that the two NPs are taken as a conjoined NP, and interpreted as the agent of the event. It appears that the agent of bidirectional constructions is the two actors of the event because they undergo the same effect in the action (they are walking or kissing together). We propose that semantic information (saliency, volitionality) can be represented in a linguistic format (e.g., [ \pm vol]). A second, still linguistic, explanation can be that bidirectional constructions are represented mentally as NP+NP-constructions. This approach claims that these constructions are redescribed semantically into a synonymous construction, such as Mary and John were kissing. This approach suggests that the transformation of NVN into NNV takes time. One could also argue that bidirectional constructions, instead of having only one agent, have two agents that are equal participants in the event. Under either explanation, the results show that the linking of agent to the Subject position is harder after a bidirecional construction.

A third explanation for the anaphor-binding advantage in the agent/ patient condition is that the agent of an agent/patient construction is 
more activated and available in the situational model, thus, more easily reactivated at the point of the anaphor. This approach (the situational or simulational account) explains the difference of reading times of the anaphors in terms of non-linguistic mental models (situation models; Zwaan-Radvansky 1998).

Taken together, both the linguistic-propositional (form-based) and the situational account can explain the pattern of results in our experiments. The hybrid model of text comprehension claims that the situational model is only one of the factors influencing linguistic processing. (The eliminative model, on the other hand, proposes that any comprehension process is finally based on the situational model.) Further research is needed to be able to opt for one of these models. We could only show with the methodology at hand that a fine-grained semantic distinction is represented during language comprehension. However, we could not demonstrate exactly at which level this distinction is represented, and what information goes exactly into the linguistic, syntactic and propositional representation. It may well be the case that thematic roles, which are heavily loaded semantically, disambiguate the bi- vs. unidirectional readings, rather than situation models. We believe that the subtle semantic difference between the agent status of uni- and bidirectional constructions $([ \pm \mathrm{vol}])$ is finally represented in the mental model (situational model) in a non-linguistic format.

An alternative conception of the hybrid model is that the thematic representation is a (formal-linguistic) description and simplification of the situational representation. What this amounts to is that thematic representations are equivalent to the elements of non-linguistic situational models. They are the ultimate theoretical constructs of situational models. This approach, therefore, is at odds with the view that thematic roles and situational models are qualitatively different.

Future research should focus on the question of the saliency of the subject. It may be the case that certain verbs require the agent to be "more agentive" (asymmetric verbs) than others (symmetric verbs). The question of agency is as follows: is there a difference in the representation of Mary kissed John (volitional agent) versus Mary was kissing with John (non-volitional agent)? A self-paced reading experiment should shed light on the reactivation of Subject-antecedents in both cases. We expect antecedent reactivation (the binding of the Subject-NP) to be faster in the volitional agent case (Mary kissed John) because a volitional agent is a more prototypical agent (proto-agent) in terms of the proto-roles 
proposed by Dowty (1991). In his conception, the NP with the highest number of properties of the Proto-Agent tends to be treated as the Agent in the sentence.

\section{References}

Adams, Brian C.-Charles Clifton Jr.-Don C. Mitchell 1998. Lexical guidance in sentence processing? In: Psychonomic Bulletin and Review 5:265-70.

Boroditsky, Lera 2000. Metaphoric structuring: Understanding time through spatial metaphors. In: Cognition $75: 1-28$.

Carlson, Gregory N.-Michael K. Tanenhaus 1988. Thematic roles and language comprehension. In: Syntax and Semantics $21: 263-88$.

Craik, Kenneth 1943. The nature of explanation. Cambridge University Press, Cambridge.

Dimitriadis, Alexis 2008. The event structure of irreduciably symmetric reciprocals. In: Johannes Dölling - Tatjana Heyde-Zybatow-Martin Schäfer (eds): Event structures in linguistic form and interpretation, 327-54. Walter de Gruyter, Berlin.

Dowty, David 1991. Thematic proto-roles and argument selection. In: Language 67: 547-619.

É. Kiss, Katalin 2002. The syntax of Hungarian. Cambridge University Press, Cambridge.

Gervain, Judit-Csaba Pléh 2004. Anna a hajón gondolkodik, avagy vonzatelvárások magyar mondatmegértésben [Anna is thinking on the ship, or argument expectancies in Hungarian sentence understanding]. In: Judit Gervain - Csaba Pléh (eds): A láthatatlan megismerés [The unseen cognition], 112-25. Gondolat, Budapest.

Glenberg, Arthur M.-Michael P. Kaschak 2002. Grounding language in action. In: Psychonomic Bulletin and Review 9:558-65.

Goldberg, Adele E. 1995. Constructions: A construction grammar approach to argument structure. The University of Chicago Press, Chicago.

Gompel, Roger P. G. van-Martin J. Pickering 2001. Lexical guidance in sentence processing: A note on Adams, Clifton, and Mitchell 1998. In: Psychonomic Bulletin and Review $8: 851-7$.

Halácsy, Péter-András Kornai-László Németh-András Rung-István Szakadát - Viktor Trón 2004. Creating open language resources for Hungarian. In: Maria Teresa Lino - Maria Francisca Xavier - Fátima Ferreira - Rute Costa - Raquel Silva (eds): Proceedings of the 4th International Conference on Language Resources and Evaluation (LREC2004), 203-10. European Language Resource Association, Paris.

Hankamer, Jorge-Ivan Sag 1976. Deep and surface anaphora. In: Linguistic Inquiry $7: 391-428$

Johnson-Laird, Philip N. 1983. Mental models: Towards a cognitive science of language, inference, and consciousness. Cambridge University Press \& Harvard University Press, Cambridge \& Cambridge, MA. 
Just, Marcel Adam-Patricia A. Carpenter-Jacqueline D. Woolley 1982. Paradigms and process in reading comprehension. In: Journal of Experimental Psychology $111: 228-38$.

Kaschak, Michael P.-Arthur M. Glenberg 2000. Constructing meaning: The role of affordances and grammatical constructions in language comprehension. In: Journal of Memory and Language 43:508-29.

Kehler, Andrew 2002. Coherence, reference, and the theory of grammar. CSLI Publications, Stanford, CA.

Kintsch, Walter 1998. Comprehension: a paradigm for cognition. Cambridge University Press, Cambridge.

Kornai, András-Péter Halácsy-Viktor Nagy-Csaba Oravecz-Viktor Trón-Dániel Varga 2006. Web-based frequency dictionaries for medium density languages. In: Adam Kilgarriff - Marco Baroni (eds): Proceedings of the 2nd International Workshop on Web as Corpus, ACL-06: 1-9. Association for Computational Linguistics, Trento. (http://acl.ldc.upenn.edu/W/W06/W06-1701.pdf)

Levin, Beth 1993. English verb classes and alternations. University of Chicago Press, Chicago.

MacDonald, Maryellen C. - Neal J. Pearlmutter-Mark S. Seidenberg 1994. The lexical nature of syntactic ambiguity resolution. In: Psychological Review 101:676-703.

Marr, David 1982. Vision: A computational investigation into the human representation and processing of visual information. W. H. Freeman, San Francisco.

Mitchell, Don C. 1987. Lexical guidance in human parsing: Locus and processing characteristics. In: Max Coltheart (ed.): Attention and performance XII, 601-18. Erlbaum, Hillsdale, NJ.

Pléh, Csaba 1989. Formal connexity and pragmatic cohesion in anaphora interpretation. In: Maria-Elisabeth Conte-Sándor János Petőfi-Emel Sözer (eds): Text and discourse connectedness. Proceedings of the Conference on Connexity and Coherance, Urbino, 1989, 137-52. John Benjamins, Amsterdam \& Philadelphia.

Pléh, Csaba 1998. A mondatmegértés a magyar nyelvben [Sentence interpretation in Hungarian]. Osiris Kiadó, Budapest.

Pléh, Csaba-Brian MacWhinney 1987. Anaphora resolution in Hungarian. In: Acta Linguistica Hungarica $37: 103-24$.

Prichett, Bradley L. 1992. Grammatical competence and parsing performance. Chicago University Press, Chicago \& London.

Rákosi, György 2003. Comitative arguments in Hungarian. In: UiL-OTS Yearbook 2003, 47-57. Utrecht institute of Linguistics OTS, Utrecht.

Richardson, Daniel C. - Michael J. Spivey-Lawrence W. Barsalou-Ken McRae 2003. Spatial representations activated during real-time comprehension of words. In: Cognitive Science $27: 767-80$.

Sag, Ivan-Jorge Hankamer 1984. Toward a theory of anaphoric processing. In: Linguistics and Philosophy $7: 325-45$.

Stanfield, Robert A.-Rolf A. Zwaan 2001. The effect of implied orientation derived from verbal context on picture recognition. In: Psychological Science 12:153-6. 
Zwaan, Rolf A.-Carol J. Madden-Richard H. Yaxley-Mark E. Aveyard 2004. Moving words: Dynamic representations in language comprehension. In: Cognitive Science $28: 611-9$.

Zwaan, Rolf A.-Gabriel A. Radvansky 1998. Situation models in language comprehension and memory. In: Psychological Bulletin 123:162-85.

\section{Appendix A}

Stimulus sentences in Experiments 1 and 2 (the sentences were presented in the NNVsetting in Experiment 1; and in Experiment 2 in an NVN-setting).

A lány a fiúval bulizott. Összejöttek másnap.

'The girl partied with the boy. They hooked up the day after.'

A lány a fiúval bulizott. Összejött vele.

'The girl partied with the boy. She hooked up with him.'

A lány a fiúval sétálgatott. Nevetgéltek közben.

'The girl was walking with the boy. They were giggling.'

A lány a fiúval sétálgatott. Nevetgélt közben.

'The girl was walking with the boy. She was giggling.'

A hölgy az úrral találkozott. Elmosolyodtak.

'The lady met up with the gent. They broke into a smile.'

A hölgy az úrral találkozott. Elmosolyodott.

'The lady met up with the gent. She broke into a smile.'

A hentes a füszeressel tegeződött. Összebarátkoztak később.

'The butcher was on friendly terms with the grocer. They became friends afterwards.'

A hentes a füszeressel tegeződött. Összebarátkozott vele.

'The butcher was on friendly terms with the grocer. He became friends with him.'

A szakács a pékkel párbajozott. Elfáradtak.

'The cook duelled with the baker. They got tired.'

A szakács a pékkel párbajozott. Elfáradt.

'The cook duelled with the baker. He got tired.'

A pék a patikussal énekelt. Elcsendesedtek.

'The baker was singing with the pharmacist. They quieted down.'

A pék a patikussal énekelt. Elcsendesedett.

'The baker was singing with the pharmacist. He quieted down.'

A lány a fiúval csókolózott. Átkarolták egymást.

'The girl was kissing with the boy. They gave each other a hug.'

A lány a fiúval csókolózott. Átkarolta őt.

'The girl was kissing with the boy. She gave him a hug.'

A zöldséges a virágárussal verekedett. Kibékültek másnap.

'The grocer was fighting with the florist. They made it up next day.' 
A zöldséges a virágárussal verekedett. Kibékült vele.

'The grocer was fighting with the florist. He made it up with him.'

A kereskedő a halásszal borozott. Megkedvelték egymást.

'The merchant was drinking wine with the fisherman. They came to like each other.'

A kereskedő a halásszal borozott. Megkedvelte őt.

'The merchant was drinking wine with the fisherman. He came to like him.'

A hentes a zöldségessel mulatozott. Hazamentek ezután.

'The butcher racketed with the grocer. They went home afterwards.'

A hentes a zöldségessel mulatozott. Hazament ezután.

'The butcher racketed with the grocer. He went home afterwards.'

A lány a fiúval kikezdett. Összejöttek másnap.

'The girl made a pass at the boy. They hooked up with each other the day afterwards.'

A lány a fiúval kikezdett. Összejött vele.

'The girl made a pass at the boy. She hooked up with him.'

A lány a fiúval incselkedett. Nevetgéltek közben.

'The girl was teasing the boy. They both were giggling.'

A lány a fiúval incselkedett. Nevetgélt közben.

'The girl was teasing the boy. She was giggling.'

A hölgy az úrral csipkelődött. Elmosolyodtak.

'The lady was bantering with the gent. They broke into a smile.'

A hölgy az úrral csipkelödött. Elmosolyodott.

'The lady was bantering with the gent. She broke into a smile.'

A hentes a füszeressel szimpatizált. Összebarátkoztak később.

'The butcher was fond of the grocer. They became friends later on.'

A hentes a füszeressel szimpatizált. Összebarátkozott vele.

'The butcher was fond of the grocer. He became his friend.'

A szakács a pékkel foglalkozott. Elfáradtak.

'The cook was dealing with the baker. They got tired.'

A szakács a pékkel foglalkozott. Elfáradt.

'The cook was dealing with the baker. He got tired.'

A pék a patikussal ordított. Elcsendesedtek.

'The baker was shouting at the baker. They quieted down.'

A pék a patikussal ordított. Elcsendesedett.

'The baker was shouting at the baker. He quieted down.'
A lány
a fiúval
együttérzett. Átkarolták
egymást.

'The girl sympathized with the boy. They hugged each other.'

A lány a fiúval együttérzett. Átkarolta őt.

'The girl sympathized with the boy. She gave him a hug.'

A zöldséges a virágárussal csúfolódott. Kibékültek másnap.

'The grocer was mocking the florist. They made it up the day after.' 
A zöldséges a virágárussal csúfolódott. Kibékült vele.

'The grocer was mocking the florist. He made it up with him.'

A kereskedő a halásszal törődött. Megkedvelték egymást.

'The merchant was caring for the fisherman. They came to like each other.'

A kereskedő a halásszal törődött. Megkedvelte őt.

'The merchant was caring for the fisherman. He came to like him.'

A hentes a zöldségessel gúnyolódott. Hazamentek ezután.

'The butcher was mocking the grocer. They went home afterwards.'

A hentes a zöldségessel gúnyolódott. Hazament ezután.

'The butcher was mocking the grocer. He went home afterwards.'

\section{Appendix B}

The lemma frequencies (MOKK) of the critical verbs in Experiments 1 and 2 .

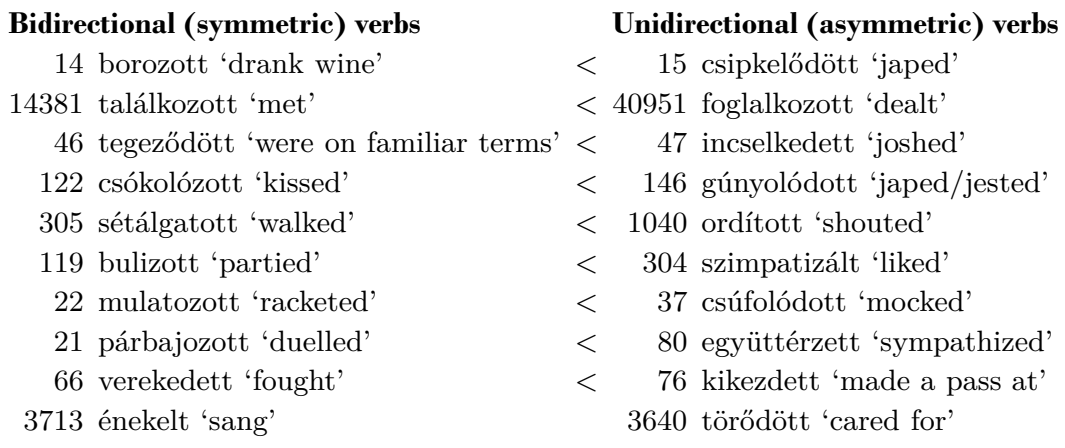

\section{Appendix C}

\section{Bidirectional (symmetric) verbs}

összeházasodott 'got married with' együttmaradt 'stayed together with' elbeszélgetett 'had a chat with' megismerkedett 'got acquainted with' összekülönbözött 'fell out with' összefogott 'joined with' összeköltözött 'moved together with' összebeszélt 'ganged up with' összeszólalkozott 'came to loggerheads with' találkozott 'met up with'

\author{
Unidirectional (asymmetric) verbs \\ szakított 'broke up with' \\ kikezdett 'made a pass at' \\ szimpatizált 'liked' \\ törődött 'cared for' \\ foglalkozott 'dealt with' \\ leszámolt 'got equal with' \\ veszödött 'bothered with' \\ kivételezett 'favoured' \\ kiszúrt 'picked on' \\ elbánt 'made a score with'
}

Acta Linguistica Hungarica 58, 2011 